\title{
MICROSATELLITE MARKERS FOR IDENTIFICATION OF Prunus spp. ROOTSTOCKS
}

\author{
Valmor João Bianchi ${ }^{1 *}$; Silviero Sansavini²; José Carlos Fachinello ${ }^{1}$ \\ ${ }^{1}$ UFPel - Depto. de Fitotecnia, C.P. 354 - 96010-900 - Pelotas, RS - Brasil. \\ ${ }^{2}$ UNIBO - Diparto. di Colture Arboree, Via G. Fanin - 4640126 - Bologna, Italia. \\ *Corresponding author <valmorjb@yahoo.com>
}

\begin{abstract}
Cultivar characterization for fruit trees certification requires fast, efficient and reliable techniques. Microsatellite markers (SSR) were used in the molecular characterization of 29 Prunus spp. rootstocks. The DNA from the rootstocks was analyzed using five pre-selected SSR primers (UDP96-005, UDP96-008, UDP96013, UDP96-18 and UDP98-414) and revealed 81 alleles, which allowed each genotype to be identified. The UDP96-005 marker generated the most information, i.e., 23 well-distributed, polymorphic alleles among all genotypes. The 21 polymorphisms produced by UDP96-013 occurred mainly as a result of high degree of variability among genotypes of the Prunophora subgenus. In the dendrogram, the five markers allowed the 29 rootstocks to be grouped into subgroups corresponding to the subgenus they belong to, either Prunophora or Amygdalus. Suitable cophenetic correlation coefficient $(\mathrm{r}=0.82)$ and good bootstrapping fitting value among the Prunophora subgroup cultivars were obtained. SSR markers proved to be efficient and reliable for the molecular characterization of Prunus spp. rootostocks.
\end{abstract}

Key words: peach tree, SSR, fingerprinting

\section{IDENTIFICAÇÃO DE PORTA-ENXERTOS DE Prunus spp. COM MARCADORES MICROSSATÉLITES}

\begin{abstract}
RESUMO: A caracterização de cultivares na produção de mudas certificadas exige técnicas rápidas, eficientes e confiáveis. Marcadores microssatélites (SSR) foram utilizados objetivando a caracterização molecular de 29 porta-enxertos de Prunus spp. O DNA dos porta-enxertos foi analisado utilizando cinco primers SSR préselecionados (UDP96-005, UDP96-008, UDP96-013, UDP96-18 e UDP98-414) e revelaram um total de 81 alelos que permitiram individualizar cada um dos genótipos. UDP96-005 foi o marcador que produziu o maior número de informação, 23 alelos polimórficos bem distribuídos entre todos os genótipos. Os 21 polimorfismos produzidos por UDP96-013 ocorreram principalmente pelo elevado grau de variabilidade entre genótipos do subgênero Prunophora. Os cinco marcadores permitiram a separação dos 29 porta-enxertos, no dendrograma, em subgrupos correspondentes aos subgêneros a que pertencem, Prunophora e Amygdalus. Foram obtidos valores adequados para o coeficiente de correlação cofenética $(r=0,82)$ e de "bootstrapping" entre os cultivares do subgrupo Prunophora. Os SSR são eficientes e confiáveis para a caracterização molecular de porta-enxertos de Prunus spp.

Palavras-chave: pessegueiro, SSR, fingerprinting
\end{abstract}

\section{INTRODUCTION}

In Brazil, stonefruit trees are produced by grafting cultivars onto self-rooted rootstocks, obtained from seeds collected at preserves companies, without any genetic warranty of the material that undergoes the multiplication process. In countries with greater tradition in the production of fruits and fruit trees, most rootstocks come from a clonal source and possess high health and genetic quality. In this process, the objectives of genetic certification are to describe and recognize the plant material in every step of production.

Until recently, the discrimination of varieties was based on morpho-phenological evaluation (Sansavini, 1998). However, several factors act to limit this type of analysis since many characteristics are subjectively interpreted and, because they suffer influences from the environment, it is difficult to identify genotypes correctly (Vinatzer et al., 1999). In addition, many characteristics can only be recorded when a plant reaches the adult stage or after fruiting (Weeden \& Lamb, 1985).

Because of their greater speediness, efficiency and reproducibility, the use of molecular markers based on Polymerase Chain Reaction (PCR) has been the choice in genetic studies of plants and in preparing fingerprinting for many fruit species. These markers can be used for varietal control allowing a plant to be identified at any stage or vegetative cycle (Sansavini, 1998), and can solve cases involving plants with uncertain names and sources (Filippetti et al., 1999). 
One area for the potential application of fingerprinting is the identification of rootstocks. Landry et al. (1994) and Autio et al. (1998) working with apple trees, and Lu et al. (1996) analyzing rootstocks of the Prunus genus, verified that the use of molecular techniques is suitable for identifying rootstocks, since these are either multiplied in the nursery or grafted, providing a reduced number of characteristics, thus making the identification of the material a difficult task.

In this work, microsatellite markers (SSR) were used in the characterization of 29 Prunus spp. rootstocks, aiming to produce a molecular standard which could provide a warranty of genetic identity during the multiplication stages.

\section{MATERIAL AND METHODS}

Twenty-nine Prunus spp. rootstocks from several species were utilized and among them, 13 came from a hybrid source (Table 1).

The molecular analyses were conducted in Bologna, Italy, from December, 2000 through May, 2001. The total DNA was extracted from a 50-mg, freeze-dried sample of young leaves, as described by Mulcahy et al. (1993), with modifications proposed by Bianchi et al. (2002). After treatment with RNAse, the DNA samples were diluted to a final concentration of $50 \mathrm{ng} \mu \mathrm{L}^{-1}$, in sterilized water.

Nine pairs of microsatellite primers (UDP96-001, UDP96-003, UDP96-005, UDP96-008, UDP96-013, UDP96-018, UDP98-407, UDP98-412, and UDP98-414) were analyzed, and sequences are described in Cipriani et al. (1999). The amplification reactions were conducted in a MJ PTC-100 thermocycler in a $25 \mu \mathrm{L}$ volume con-

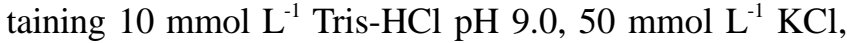
$1.5 \mathrm{mmol} \mathrm{L}^{-1} \mathrm{MgCl}_{2} 0.2 \mathrm{mmol} \mathrm{L}{ }^{-1}$ of each dNTP, $0.2 \mathrm{mmol} \mathrm{L}^{-1}$ of each primer, $0.1 \mathrm{U}$ Taq polymerase (Pharmacia) and $50 \mathrm{ng}$ genomic DNA.

The program used in the PCR reactions consisted of one cycle at $95^{\circ} \mathrm{C}$ for $5 \mathrm{~min}, 35$ cycles at $94^{\circ} \mathrm{C}$ for 45 $\mathrm{s} ; 57^{\circ} \mathrm{C}$ for $45 \mathrm{~s}$ and $72^{\circ} \mathrm{C}$ for $45 \mathrm{~s}$, followed by a final cycle at $72^{\circ} \mathrm{C}$ for $8 \mathrm{~min}$. In the reactions with primers UDP96-005 and UDP96-008, an annealing temperature of $59^{\circ} \mathrm{C}$ for $45 \mathrm{~s}$ was utilized. After PCR, $10 \mu \mathrm{L}$ of a denaturing solution ( $98 \%$ formamide, $10 \mathrm{mmol} \mathrm{L}^{-1}$ EDTA, $0.05 \%$ bromophenol blue, and $0.05 \%$ xylene cyanol) were added to each tube, followed by thermal treatment at $95^{\circ} \mathrm{C}$ for $5 \mathrm{~min}$. Of the amplified samples, $4.5 \mu \mathrm{L}$ were applied in a $6 \%$ polyacrylamide gel, in $1 \mathrm{X}$ TBE buffer. The electrophoresis was conducted at $9 \mathrm{~V} \mathrm{~cm}^{-1}$ for 2.5 hour. Gel staining was performed with silver nitrate as described in the Silver Sequencing Promega Manual (Promega, Madison, Wisconsin, USA).

The products of SSR amplification visualized in the gel were recorded with regard to the presence (1) or absence (0) of bands to obtain a similarity matrix calculated by Lynch's coefficient (Lynch, 1990). To visualize the way cultivars were grouped, the dendrogram was prepared using the Unweighted Pair Group Mean Average method (UPGMA), and the software NTSYS.pc version 2.1 (Rohlf, 2000) was used to that effect.

\section{RESULTS AND DISCUSSION}

All nine microsatellite primers were polymorphic; however, only five, UDP96-005, UDP96-008, UDP96013, UDP96-018 and UDP98-414, were used in the joint analysis of the 29 rootstocks, which revealed a total of 81 alleles, sufficient to characterize all genotypes. The UDP96-005 marker was the most informative revealing 23 polymorphic alleles distributed among all genotypes. UDP96-013 revealed 21 polymorphic alleles determined especially by genotypes of the Prunophora subgenus (Marianna 2624, Myrabolan 29C, Damas GF 1869 and the Mr. S. series rootstocks).

Fourteen polymorphisms were obtained with UDP96-008 marker (Figure 1A), while UDP96-018 (Figure 1B) and UDP98-414 markers produced 12 and 11 polymorphisms each, respectively. The polymorphisms obtained with these three markers had a greater contribution from the interspecific hybrids.

Table 1 - Prunus spp. rootstocks from the Germplasm Bank of Universidade Federal de Pelotas, Brazil.

\begin{tabular}{ll}
\hline Amygdalus subgenus & Species \\
\hline $\begin{array}{l}\text { Rubira, Montclar, PS A5, PS B2, Okinawa, Nagano Wild, Tsukuba, Kutoh, Ohatsumano, } \\
\text { and Pavia Moscatel }\end{array}$ & Prunus persica \\
Sirio, IS 5/23, IS 2/29, and GF 677 & P. amygdalus $\times$ P. persica \\
GF 386, Hansen 536, and Hansen 2168 & P. persica $\times$ P. amygdalus \\
Flordaguard, Nemared, Nemaguard, and Cadmam & P. davidiana $\times$ P. persica \\
Prunus capuli & Prunus capuli \\
\hline Prunophora subgenus & \\
\hline Myrabolan 29C, Mr. S. 1/8, Mr. S. 1/14, Mr. S. 2/8, and Mr. S. 2/5 & Prunus cerasifera \\
Marianna 2629 & P. cerasifera $\times$ P. munsonianna \\
Damas GF 1869 & P. domestica $\times$ P. spinosa \\
\hline
\end{tabular}

Source: Grassely (1989); Loreti \& Massai (1999); Fachinello (2000). 
A $11223455 \quad 6 \quad 7 \quad 8 \quad 91011121314151617181920212223242526272829$ M
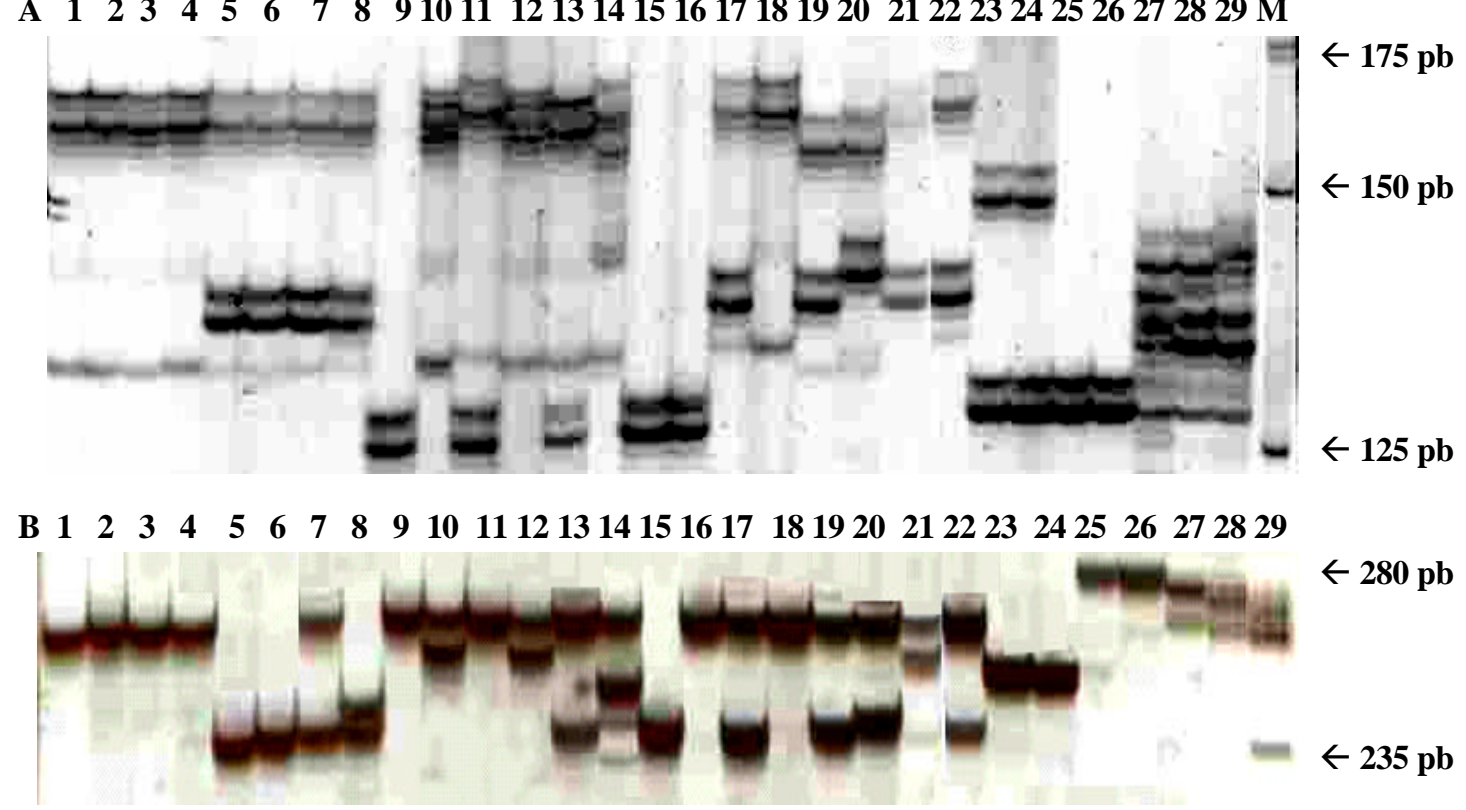

Figure 1 - Amplification products generated by microsatellite markers UDP96-008 (A) and UDP96-018 (B), for Prunus spp. rootstocks Rubirá (1), Montclar (2), PS A5 (3), PS B2 (4), Sirio (5), IS 5/23 (6), IS 5/29 (7), GF 386 (8), Okinawa (9), Nagano Wild (10), Tsukuba (11), Kutoh (12), Ohatsumano (13), Flordaguard (14), Nemared (15), Nemaguard (16), GF 677 (17), Pavia Moscatel (18), Hansen 536 (19), Hansen 2168 (20), Prunus capuli (21), Cadmam (22), Mariana 2624 (23), Myrabolan 29C (24), Mr. S. 1/8 (25), Mr. S. $1 / 14$ (26), Damas GF 1869 (27), Mr. S. $2 / 8$ (28) and Mr. S. $2 / 5$ (29). 100 bp marker (M).

For the conditions under which the PCR reactions were conducted, the number of amplified alleles (bands) in each genotype was between one and two with UDP96-018 and UDP98-414 markers. With UDP96-005, the number of amplified alleles was between one and two, with the exception of cultivar Mr. S. 1/14, which presented three alleles. Four amplified alleles were recorded with UDP96-013 for cultivar Mr. S. 2/5 and three for cultivar Mr. S. 2/8. Even though the Mr. S. series rootstocks are classified as belonging to the species $P$. cerasifera, obtained from Myrabolan seedlings (diploid), one of them, Mr. S. 2/5, revealed to be a pentaploid cultivar when the chromosomes were counted. According to Loreti \& Massai (1999), this possibly occurred as a result of pollen contamination from other species or through the occurrence of ploidy, thus explaining the presence of a greater number of alleles for the same locus in that rootstock of this serie.

The band pattern obtained for $P$. persica cultivars, analyzed in this work, is according to the size (in base pairs-bp) of microsatellites sequenced from two peach tree genomic libraries [P. persica (L.) Batsch cv. Redhaven], reported by Cipriani et al. (1999). From the 29 rootstocks analyzed, the amplified fragments were between 130 and 165 bp for UDP96-008, 235 and $280 \mathrm{bp}$ for UDP96-018, 127 and 170 bp for UDP98-414, 102 and $170 \mathrm{bp}$ for UDP96-005, and 75 and 205 bp for UDP96013. The largest scope in microsatellite size was recorded with UDP96-013 marker, through which Mr. S. 1/8, Mr.
S. 2/8 and Mr. S. 2/5 rootstocks shared a band of approximately $75 \mathrm{bp}$, while the band with the highest molecular weight was 205 bp for GF 386 rootstock. With UDP96005 , the band with the smallest molecular weight was observed in P. capuli (approximately $102 \mathrm{bp}$ ), while the largest was observed in Montclar cultivar (172 bp).

A suitable fit between the similarity matrix and the dendrogram was observed (Figure 2), since the cophenetic correlation coefficient (r) was 0.82 . The dendrogram constructed with data from the five primers allowed the 29 rootstocks to be clearly separated. The best separation of rootstocks in the dendrogram occurred among cultivars belonging to the Prunophora subgenus, consisting basically of four species: $P$. ceracifera, $P$. munsoniana, $P$. domestica, and $P$. spinosa. For genotypes of those species, concordance was verified to exist between the groupings and the genealogical data described by Loreti \& Massai (1999). The genetic similarity was 0.97 between Marianna 2624 and Myrabolan 29C, and 0.94 for Mr. S. $1 / 8$ and Mr. S. 1/14. Within this group, suitable bootstrapping values were also obtained between Marianna 2624 and Myrabolan 29C (0.98), Mr. S. 1/8 and Mr. S. 1/14 (0.84), and Mr. S. 2/5 and Mr. S. $2 / 8$ (0.54).

Among the rootstocks belonging to the Amygdalus subgenus, it can be noticed that based on data of only five SSR primers, the grouping of some rootstocks (Figure 2) did not show concordance with the genealogical data, especially for the genotype of $P$. persica Pavia Moscatel cultivar, and for Flordaguard and Nemared hy- 


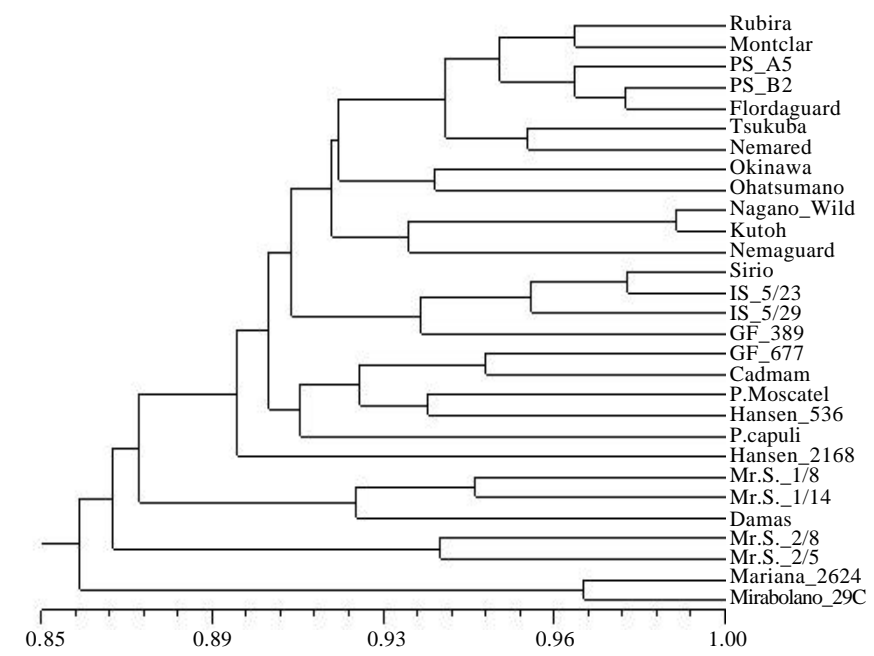

Figure 2 - Dendrogram obtained with data from five SSR markers in 29 Prunus spp. rootstocks, constructed by the UPGMA method and based on Lynch's coefficient (1990).

brid cultivars, which were grouped relatively far away from the other rootstocks of the same species or of the same hybrid class, respectively.

Among the cultivars in the Amygdalus subgroup, the highest genetic similarity indices were recorded between rootstocks Nagano Wild and Kutoh (0.99), Sirio and IS 5/23 (0.98), and between Sirio and IS 5/29 (0.95). These similarity indices result from the common genetic source of those rootstocks, the first group being of Japanese origin, while the second and third groups were both originated from the free pollination of GF 557 cultivar, a hybrid genotype of $P$. amygdalus $\times P$. persica. Among rootstocks in the Amygdalus subgenus, Sirio and IS 5/23 showed the highest bootstrapping value (0.83), followed by Nagano Wild and Kutoh (0.72).

Even though the use of only five microsatellite markers was sufficient to obtain polymorphisms for the discrimination of 29 rootstock cultivars, to study genetic variability and to obtain a grouping that was more appropriate to the respective genealogical data for these genotypes, it is necessary to use a larger number of primers to impart greater authenticity to the use of molecular markers if the objective is to make inferences about the genetic variability of those materials. Rootstocks of the Prunus spp. genus can be genetically characterized by microsatellite markers.

\section{ACKNOWLEDGEMENTS}

To Coordenadoria de Aperfeiçoamento de Pessoal de Nível Superior (CAPES) and to Conselho Nacional de Desenvolvimento Científico e Tecnológico (CNPq).

\section{REFERENCES}

AUTIO, W.R.; SCHUPP, J.R.; FERREE, D.C.; GLAVIN, R.; MULCAHY, D.L. Application of RAPDs to DNA extracted from apple rootstocks. HortScience, v.33, p.333-335, 1998.

BIANCHI, V.J.; VENTURI, S.; FACHINELLO, J.C.; TARTARINI, S.; SANSAVINI, S. I marcatori AFLP e SSR, risolutivi nella identificazione genetica delle varietà di susino. Frutticoltura, n.4, p.83-87, 2002.

CIPRIANI, G.; LOT, G.; HUANG, W.G.; MARRAZZO, M.T.; PETERLUNGER, E.; TESTOLIN, R. AC/GT and AG/CT micosatellite repeats in peach [Prunus persica (L.) Batsch]: isolation, characterization and cross-species aplication in Prunus. Theoretical and Applied Genetics, v.99, p.65-72, 1999.

FACHINELLO, J.C. Problemática das mudas de plantas frutíferas de caroço. In: SIMPÓSIO INTERNACIONAL DE FRUTAS DE CAROÇO: PÊSSEGOS, NECTARINAS E AMEIXEIRAS, 1., Porto Alegre, 2000. Anais. Porto Alegre: UFRGS, 2000. p.24-40.

FILIPPETTI, I.; INTRIERI, C.; SILVESTRONI, O. Individuazione di omonimie e di sinonimie in alcune cultivar di Vitis vinifera attraverso metodi ampelografici e analisi del DNA a mezzo di microsatelliti. Frutticoltura, n.7/8, p.79-84, 1999.

GRASSELY, C. I portinnesti del pesco selezionati in Francia. Frutticoltura, n.8/9, p.15-17, 1989.

LANDRY, B.S.; LI, R.Q.; CHEUNG, W.Y.; GRANGER, R.L. Phylogeny analysis of 25 apple rootstocks using RAPD markers and tactical gene tagging. Theoretical and Applied Genetics, v.89, p.847-852, 1994.

LORETI, F.; MASSAI, R. I portinnesti del pesco. I portinnesti dei fruttiferi. L'Informatore Agrario, p.39-44, 1999. Supplemento 6.

LU, Z.; REIGHARD, G.L.; BAIRD, W.V.; ABBOTT, A.G.; RAJAPAKSE, $\mathrm{S}$. Identification of peach rootstock cultivars by RAPD markers. HortScience, v.31, p.127-129, 1996.

LYNCH, M. The similarity index and DNA fingerprinting. Molecular Biology Evolution, v.7, p.478-484, 1990.

MULCAHY, D.L.; CRESTI, M.; SANSAVINI, S.; DOUGLAS, G.C.; LINSKENS, H.F.; BERGAMINI MULCAHY, G.; VIGNANI, R.; PANCALDI, M. The use of random amplified polymorphic DNAs to fingerprint apple genotypes. Scientia Horticulturae, v.54, p.89-96, 1993.

ROHLF, F.J. NTSYS.PC. Numerical taxonomy and multivariate analysis system. Version 2.1. New York: Exeter Publications, 2000.

SANSAVINI, S. Biotecnologie fruticole: le nuove frontiere delle ricerche per il miglioramento genetico e la propagazione delle piante da frutto. Frutticoltura, n.5, p.75-81, 1998.

VINATZER, B.; PANCALDI, M.; SANSAVINI, S. Potenzialitá e limiti del "fingerprinting" nell'identificazione varietale del pesco. Frutticoltura, n.4, p.97-101, 1999.

WEEDEN, N.F.; LAMB, R.C. Identification of apple cultivars by isozyme phenotypes. Journal of the American Society for Horticultural Science, v.110, p.509-515, 1985.

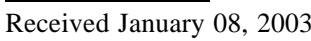

Accepted March 09, 2004 